\title{
Prosjektarbeid og postere gir studentene økt læringsgevinst
}

\section{Sykepleierstudentene ved NTNU i Ålesund jobber i} prosjektgrupper i tre uker for å lære om helsefremmende og forebyggende sykepleie. Kunnskapen deler de med andre ved å utarbeide en prosjektoppgave og en poster.

\section{Lindis Helberget}

Universitetslektor

Institutt for helsevitenskap, Norges teknisk-naturvitenskapelige universitet, Ålesund

Sven Inge Molnes

Førstelektor

Institutt for helsevitenskap, Norges teknisk-naturvitenskapelige universitet, Ålesund

Helsefremmende og forebyggende sykepleie

Prosjektarbeid

Sykepleierutdanning

Pedagogikk

Undervisning

\section{Hovedbudskap}

Prosjektarbeid som læringsaktivitet kan gi sykepleierstudenter $\varnothing \mathrm{kt}$ kompetanse i helsefremmende og forebyggende sykepleie. De siste årene har sykepleierstudentene ved Norges teknisk-naturvitenskapelige universitet (NTNU) i Ålesund arbeidet med prosjekter knyttet til helsefremmende og forebyggende sykepleie. Prosjektene har blitt presentert som postere i fellesarealene på campus, der alle kan se posterne og få mulighet til å møte sykepleierstudentene som har arbeidet med prosjektene. En kombinasjon av forelesninger, fag- og forskningslitteratur og arbeid i prosjektgrupper ga $\varnothing \mathrm{kt}$ læringsgevinst. 
De siste årene har det skjedd en rekke endringer i det norske helsevesenet. Det har vært en dreining fra en tankegang der helse- og omsorgstjenestene la vekt på behandling av lidelser, til at helsefremmende og forebyggende tiltak har fått st $\varnothing$ rre betydning.

Demografiske endringer og endringer i befolkningens helsetilstand er noen av årsakene til denne dreiningen (1-4). Videre har det blitt lagt større vekt på at pasientene er eksperter på seg selv samt på pasientmedvirkning og maktomfordeling (5).

\section{Sykepleiere må ha oppdatert kunnskap}

Helse- og omsorgstjenesten må ha ansatte med kompetanse innen primær-, sekundær- og tertiærforebygging (6). I fremtiden må sykepleiere være i stand til å utvikle sin kompetanse i tråd med befolkningens behov.

Ifølge forskrift om nasjonal retningslinje for sykepleierutdanning (7) § 2 skal sykepleierutdanningen «kvalifisere kandidater til å utøve sykepleie for å ivareta menneskets grunnleggende behov, fremme helse, forebygge og behandle sykdom, lindre lidelse og sikre en verdig d $\varnothing \mathrm{d}$. Grunnlaget for omsorgsfull og faglig forsvarlig sykepleie er oppdatert kunnskap, skikkethet og respekt for menneskers autonomi og medbestemmelse».

Dette er i tråd med forskrift om felles rammeplan for helseog sosialfagutdanninger (8) og nasjonale retningslinjer for helse- og sosialfagutdanninger (RETHOS) (9), som skal sikre samfunnets nåværende og fremtidige behov for kompetanse.

\section{Primær-, sekundær- og tertiærforebygging}

Forebyggende arbeid kan deles opp i tre nivåer: Primærforebygging som innebærer å styrke helsen og hindre at det oppstår sykdom, skade eller lyte. Sekundærforebygging som handler om å stanse sykdomsutvikling og/eller hindre tilbakefall, og det tredje nivået tertiærforebygging handler om å hindre forverring og sikre best mulig liv med den helsesvikten som foreligger (6). 


\section{Prosjektarbeid i et læringsforløp}

I Norge skal høyere utdanning tilby forskningsbasert undervisning, som er et lovfestet krav til undervisning ved universitetene og høyskolene (10-11).

Forskningsbasert undervisning kan være formidling av etablert kunnskap, av ny anerkjent kunnskap eller av forskningsresultater som nettopp har blitt kjent. Veiledning inngår som en del av den forskningsbaserte undervisningen.

\section{Studentene jobber tre uker med prosjektene}

Sykepleierstudentene ved Institutt for helsevitenskap ved NTNU i Ålesund må i løpet av tre uker gjennomføre et prosjekt som legger vekt på helsefremmende og forebyggende sykepleie. Dette arbeidet foregår nå i femte semester, men fra og med våren 2022 blir det flyttet til fjerde semester.

\section{三 «Sykepleierstudentene lærer å tenke helsefremmende og forebyggende både i et nasjonalt og internasjonalt perspektiv.»}

En av fordelene med å vektlegge helsefremmende og forebyggende arbeid tidligere i studieforløpet er at det er med på å fremme den helsefremmende tankegangen hos studentene slik at de får mulighet til å bruke det i flere praksisarenaer i utdanningen. En annen fordel er at de lærer å tenke helsefremmende og forebyggende både i et nasjonalt og internasjonalt perspektiv tidligere i studieforløpet.

\section{De får presentert aktuelle temaer}

Sykepleierstudentene får ved oppstarten av prosjektet presentert ulike temaer som er aktuelle med tanke på helsefremmende og forebyggende sykepleie.

Dette kan for eksempel være temaer som omhandler helsestasjonsarbeid (ammeveiledning, vaksinering, foreldreveiledning, helsekontroller av barn), helsefremmende og forebyggende arbeid til eldre og utsatte grupper, arbeidshelse (helse, miljø og sikkerhet), seksuell helse, forebygging av posttraumatisk stresslidelse etter seksuelle overgrep og vold i nære relasjoner og sekundærforebygging av hjerteinfarkt. 
Videre skal studentene fordype seg i blant annet sykepleieres funksjon og ansvar i helsefremmende og forebyggende arbeid, folkehelsearbeid på individ-, gruppe- og befolkningsnivå, miljø og arbeidshelse, livsfaser og helse eller svangerskap, fødsel og barseltid.

\section{Studentene skal lære om tiltak som fremmer helse}

Hensikten med prosjektet er at studentene skal vise kunnskap og forståelse for helsefremmende og forebyggende arbeid relatert til mennesker, helse, miljø og sykepleie. De skal presentere og diskutere tiltak som fremmer helse i møte med mennesker i ulike aldre og livssituasjoner.

\section{Forberedelse, gjennomføring og evaluering}

Det er flere temaer sykepleierstudentene kan velge mellom, og de skal selv utarbeide en problemstilling, men læringsutbyttene i hvert emne legger noen føringer.

Emnet har læringsutbytter som er dekkende for de ulike temaene studentene kan velge mellom. Studentene kan selv $\varnothing$ nske seg tema, men der det er flere prosjektgrupper som $\varnothing$ nsker det samme temaet, blir det gjennomført en trekning.

\section{$\equiv \ll$ Studentene kan selv ønske seg tema.»}

En prosjektgruppe består av inntil fem personer. Studentene velger selv hvem de vil være i prosjektgruppe med. Før sykepleierstudentene begynner på selve prosjektarbeidet, får de innføring i flere av temaene gjennom forelesninger, selvstudium og gruppearbeid.

\section{Oppgaven skal organiseres etter IMRoD-strukturen}

Sykepleierstudentene skal utarbeide en prosjektoppgave, som organiseres etter IMRoD-strukturen (Introduksjon, Metode, Resultat og Diskusjon). I introduksjonen skal de presentere bakgrunn, problemstilling og teoretisk perspektiv.

Når det gjelder metode, er dette en litteraturstudie der studentene skal gjennomf $\varnothing$ re et systematisk litteraturs $\varnothing \mathrm{k}$. De skal beskrive kort hvordan de fant minimum fire forskningsartikler, og redegjøre for s $\varnothing$ kestrategi, s $\varnothing$ keord, valg av database og eventuelt andre datakilder. 
De skal i resultatdelen $1 \varnothing f t e$ frem det de fant i

forskningsartiklene og i eventuelt andre kilder. Diskusjonen skal ta for seg hvordan de vil iverksette helsefremmende og forebyggende sykepleietiltak til den aktuelle målgruppen. De avslutter oppgaven med en konklusjon.

\section{Studentene får veiledning}

Sykepleierstudentene får tilbud om to veiledningssamtaler. Den ene er rettet mot problemstillingen, mens den andre veiledningen dreier seg om prosjektoppgaven.

\section{$\equiv$ «Sykepleierstudentene skal etter endt prosjektperiode levere inn prosjektoppgaven.»}

Sykepleierstudentene skal etter endt prosjektperiode levere inn prosjektoppgaven. De får karakteren bestått/ikke bestått på prosjektoppgaven. Videre skal studentene utarbeide en poster og presentere denne.

\section{Postere er en del av læringsaktiviteten}

Sykepleierstudentene skal utarbeide en poster etter IMRoDstrukturen og presentere den i fellesarealet på campus, for både medstudenter og andre sykepleiestudenter på ulike årstrinn. I tilknytningen til posterutstillingen blir det arrangert en uformell kåring av beste poster.

Hensikten med å benytte poster som en læringsaktivitet er at vi ser nytten av å kunne kombinere forskning og fagutvikling. Sykepleierstudentene har gjennom prosjektarbeidet innhentet etablert kunnskap, ny anerkjent kunnskap eller forskningsresultater som nettopp har blitt kjent.

Prosjektarbeidet er viktig å formidle videre til medstudenter, faglærere og andre som har interesse for temaet.

\section{De får øvelse i å formidle et tema}

Sykepleierstudentene får videre trening i å presentere en poster, der de må tenke layout. Studentene tar utgangspunkt i en mal, som er strukturert etter IMRoD (eksempel 1), men de står fritt til å gjøre det de ønsker (eksempel 2 og 3).

\section{三 $\ll$ Mange finner det utfordrende å komprimere en hel prosjektoppgave til en poster.»}


Mange finner det utfordrende å komprimere en hel prosjektoppgave til en poster. De får øvelse i å formidle et tema på en måte som gjør publikum nysgjerrige og interesserte, samtidig som de får formidlet hovedinnholdet i prosjektet. Flere har oppdaget at en godt layout er med på å fange publikum.

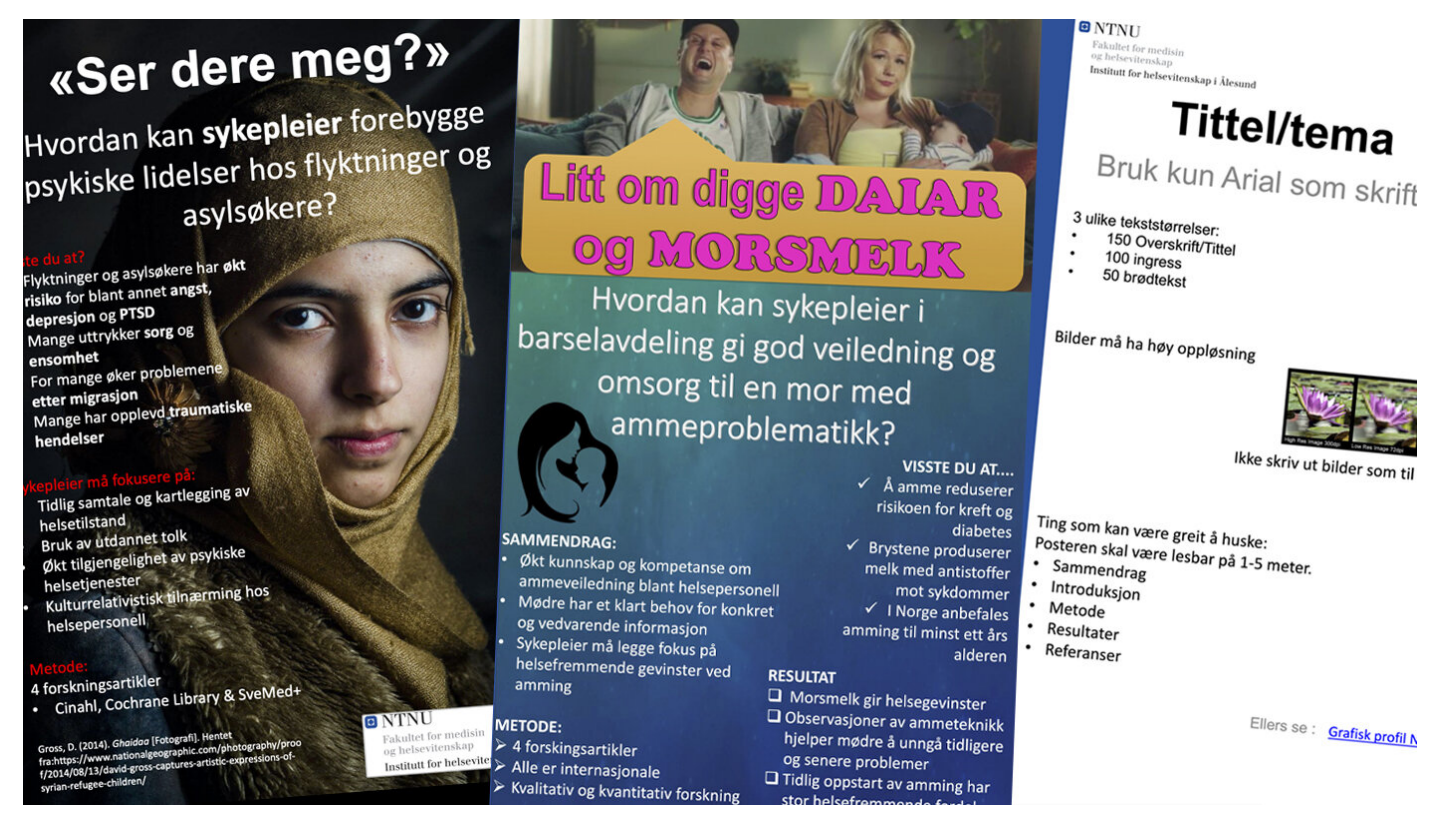

POSTERE OG MAL: To postere som studentene ved Institutt for helsevitenskap ved NTNU i Ålesund har lagd, og malen de tok utgangspunkt i når de lagde posterne (eksempel 1, 2 og 3). Posterne er publisert med tillatelse fra NTNU.

\section{Studentene er fornøyde}

Sykepleierstudentene har gjennom møter i referansegrupper og referansegrupperapporter gitt gode tilbakemeldinger på det å arbeide med prosjektarbeid. De mente at de lærte mye om prosjektarbeid, men også om ulike temaer innenfor helsefremmende og forebyggende sykepleie.

Studentene syntes det var en fin introduksjon til hvordan de kan jobbe flere sammen, og hvordan de kan løse en såpass stor oppgave. Sykepleierstudentene synes det er positivt at de selv får velge hvem de vil være i gruppe med, og de mener at det er med på å gjøre samarbeidet innad i gruppene lettere.

Sykepleierstudentene finner omfanget på oppgaven tilfredsstillende, og de er godt fornøyde med veiledningen som blir gitt.

\section{De lærte mer om litteratursøk}

Studentene ga også tilbakemelding om at det er en svært god måte å lære seg mer om systematisk litteraturs $\varnothing \mathrm{k}$ på, og at de synes det er positivt med tanke på det kommende arbeidet med avsluttende bacheloroppgave. 
Når det gjelder posterutstillingen, er de fleste forn øyde, men flere oppdaget at layouten kan være avgjørende for om publikum stopper opp eller går videre. Det er mye som skal gjøres på tre uker, og noen måtte prioritere prosjektoppgaven fremfor layouten på posteren.

\section{Diskusjon}

Bruk av prosjekttenkning innenfor helsefremmende og forebyggende sykepleie kan være nyttig for sykepleierstudentene fordi det er et emne som egner seg godt til tverrprofesjonelt samarbeid.

Studentene fordyper seg i temaer om brukermedvirkning og rehabilitering til pasientgrupper som de vil møte i praksis.

\section{Studentene får kjennskap til pasientenes rettigheter}

Brukermedvirkning på individnivå handler om den enkeltes rettigheter og muligheter til å påvirke hjelpe- og behandlingstilbudet (12), og er et lovpålagt prinsipp i helsetjenesten i dag, som involverer både pasienter og pårørende (1). Det er viktig at sykepleierstudentene har kjennskap til dette for å kunne bli gode sykepleiere når de er ferdig utdannet.

Rehabilitering handler om å gjenvinne fysisk, mental eller sosial funksjonsevne som er tapt på grunn av sykdom eller skade, der målet er å gjøre den enkelte i stand til å mestre livet sitt, være selvstendig og fungere så godt som mulig i dagliglivet ut ifra sine forutsetninger og ønsker (13).

\section{Kolbs teori om læring}

Ifølge Kolb (14) konstruerer studentene sin læring gjennom ulike rammeverk. Kolbs teori er at læring er en prosess hvor kunnskap blir formet gjennom erfaringer i fire steg.

Steg én handler om at studentene står i en situasjon og opplever en konkret handling, og steg to er at studentene reflekterer over sine erfaringer og hva de betyr.

Det tredje steget er å trekke ut det vesentlige, de reflekterte observasjonene som kan være med å strukturere, generalisere og formalisere læringsutbyttene av studentenes erfaringer, og det siste og fjerde steget omhandler at denne kunnskapen kan bli testet i nye kontekster (14). Refleksjon er et av hovedelementene for at studentene skal oppnå ny kunnskap (14). 
Gjennom prosjektarbeid i helsefremmende og forebyggende sykepleie arbeider sykepleierstudentene seg spesielt gjennom steg tre og fire i teorien til Kolb (14).

\section{Studentene setter kunnskapen inn i nye kontekster}

Sykepleierstudentene abstraherer prosjektarbeidet gjennom at arbeidet deres blir strukturert og formalisert sett opp imot læringsutbyttene til sykepleierstudentene. Sykepleierstudentene har gjennom prosjektarbeidet fordypet seg i et spesielt tema, og de vil nå kunne trekke ut det vesentlige i det de har lært, vurdere hvilke konsekvenser noe făr, hvordan de kan anvende det de har lært, og hvordan de kan planlegge bedre neste gang ut fra de erfaringene de har gjort seg.

Når studentene arbeider med prosjekt, må de sette den nye kunnskapen inn i nye kontekster, og det bidrar til $\varnothing \mathrm{kt}$ forståelse for og innsikt i den helsefremmende tenkningen.

\section{三 «Når studentene deltar i prosjektarbeid, må de samarbeide og tenke team.»}

Prosjektarbeid kan bidra til økt læring i andre emner.

Studentene ser at de kan overføre kunnskapen de får om helsefremmende og forebyggende sykepleie til andre emner, som de har i løpet av sykepleierutdanningen.

Å lære studentene å bruke emner og fag i ulike kontekster er viktig for at de skal oppnå økt forståelse og lære seg å se helheten som kommende sykepleiere.

Når studentene deltar i prosjektarbeid, må de samarbeide og tenke team. Den enkelte student bidrar med sin kunnskap og det gir mestringsfølelse. Læringen forgår gjennom aktiviteter studentene gjør i fellesskap, gjerne ledet av egen nysgjerrighet, noe som er en av de mest effektive formene for læring (15).

\section{Underviseren skal motivere studentene}

Hovedoppgaven til underviseren er ikke å presentere all kunnskapen i auditoriet, men å motivere studentene til å skape et aktivt og utforskende fellesskap for læring der de i samarbeid innhenter kunnskap og planlegger prosessen videre (16). 


\section{«Hovedoppgaven til underviseren er ikke å presentere all kunnskapen $\mathbf{i}$ auditoriet, men å motivere studentene.»}

Prosjektarbeidet i helsefremmende og forebyggende sykepleie handler nettopp om at sykepleierstudentene må strukturere arbeidet sitt selv, men at veilederen/læreren har noe veiledning med gruppene og gir dem råd om hvordan de skal gå videre i prosjektarbeidet.

\section{Konklusjon}

For sykepleierstudenter er prosjektarbeid og posterpresentasjon gode læringsaktiviteter når de skal tilegne seg kompetanse i helsefremmende og forebyggende sykepleie.

Vi ser at et strukturert læringsforløp, som kombinerer forelesninger, fag- og forskningslitteratur og arbeid i prosjektgrupper, kan gi en $\varnothing \mathrm{kt}$ læringsgevinst. Forståelsen for forskning og fagutvikling hos studentene blir styrket, samtidig som de får testet ut formidlingsevnen gjennom posterpresentasjonen. Videre ser vi nytten av prosjektarbeid, der sykepleierstudentene må forholde seg til hverandre og tenke team.

\section{Referanser}

1. St. meld. nr. 47 (2008-2009). Samhandlingsreformen. Rett behandling - på rett sted - til rett til. Oslo: Helse- og omsorgsdepartementet; 2009.

2. Meld. St. 16 (2010-2011). Nasjonal helse- og omsorgsplan (2011-2015). Oslo: Departementenes servicesenter; 2011.

3. Meld. St. 19 (2014-2015). Folkehelsemeldingen. Mestring og muligheter (2014-2015). Oslo: Helse- og omsorgsdepartementet; 2015.

4. Meld. St. 34 (2012-2013). Folkehelsemeldingen. God helse - felles ansvar (2012-2013). Oslo: Departementenes servicesenter; 2013.

5. World Health Organization (WHO). Ottawa charter for health promotion. Genève: WHO; 1986. 
6. Prop. 90 L. (2010-2011) om folkehelsearbeid

(folkehelseloven). Tilgjengelig fra:

https://www.regjeringen.no/no/dokumenter/prop-9o-1-

20102011/id638503/ (nedlastet 04.09.2020).

7. Forskrift 15. mars 2019 nr. 412 om nasjonal retningslinje for sykepleierutdanning. Tilgjengelig fra:

https://lovdata.no/dokument/SF/forskrift/2019-03-15-412

(nedlastet 04.09.2020).

8. Forskrift 6. september $2017 \mathrm{nr} .1353$ om felles

rammeplan for helse- og sosialfagutdanninger. Tilgjengelig

fra: https://lovdata.no/dokument/SF/forskrift/2017-09-06-1353

(nedlastet 04.09.2020).

9. Kunnskapsdepartementet. Nasjonale retningslinjer for helse- og sosialfagutdanningene (RETHOS). Oslo:

Kunnskapsdepartementet; 2020. Tilgjengelig fra:

https://www.regjeringen.no/no/tema/utdanning/hoyere-

utdanning/utvikling-av-nasjonale-retningslinjer-for-helse--ogsosialfagutdanningene/id2569499/ (nedlastet 18.5.2020).

10. Lov 1. april $2005 \mathrm{nr} .15$ om universiteter og høyskoler (universitets- og høyskoleloven). Tilgjengelig fra:

https://lovdata.no/dokument/NL/lov/2005-04-01-15 (nedlastet 04.09.2020).

11. Meld. St. nr. 13 (2011-2012). Utdanning for velferd.

Samspill i praksis. Oslo: Kunnskapsdepartementet; 2012.

12. Alm TA. Nye behandlere og nye brukere. I: Fossest $\varnothing 1 \mathrm{~K}$, red. Relasjonsmestrere. Om kunnskapsarbeid i det nye arbeidslivet. Oslo: Gyldendal Akademisk; 2004. s. 52-9.

13. Forskrift 2011 hefte 13 om habilitering og rehabilitering, individuell plan og koordinator. Tilgjengelig fra:

https://lovdata.no/dokument/SF/forskrift/2011-12-16-1256

(nedlastet 04.09.2020).

14. Kolb DA. Experiential learning: Experience as the source of learning and development. New Jersey: Prentice-Hall; 1984.

15. Committee of Inquiry into the Changing Learner

Experience. Higher education in a Web 2.0 world: report of an independent Committee of Inquiry into the impact on higher education of students' widespread use of Web 2.0

technologies. London: JISC; 2009. 
16. Garrison DR. E-learning in the 21st Century. A

framework for research and practice. 2. utg. New York:

Routledge; 2011. 